\title{
Key predictors of modern contraceptive use among women in marital relationship in South-West region of Nigeria
}

\section{Muyiwa Oladosun*, Moses Akanbi, Fagbeminiyi Fasina, Olugbemisola Samuel}

\begin{abstract}
Department of Economics and Development Studies, Public-Private Partnership Research Cluster, Covenant University, Ota, Ogun State, Nigeria
\end{abstract}

Received: 13 April 2019

Accepted: 05 June 2019

\section{*Correspondence:}

Dr. Muyiwa Oladosun,

E-mail: muyiwa.oladosun@ covenantuniversity.edu.ng

Copyright: (c) the author(s), publisher and licensee Medip Academy. This is an open-access article distributed under the terms of the Creative Commons Attribution Non-Commercial License, which permits unrestricted non-commercial use, distribution, and reproduction in any medium, provided the original work is properly cited.

\section{ABSTRACT}

Background: Nigeria's population is the seventh largest in the world and is projected to be the fourth largest by 2050. The demographic scenario is akin by persistent high fertility and low contraceptive use. This paper examined factors influencing contraceptive use among women in marital relationship in south-west region which has the highest percentage of use compared to other regions.

Methods: A sub-sample of 3,784 women in marital relationship in the south-west region aged 15-49 was extracted from the 38,945 nationally representative samples of the 2013 Nigeria Demographic and Health Survey (NDHS). The dependent variable was contraceptive use, and key predictors include fertility behavior, employment, agents of modernity, and background factors. Logistics regression techniques were used in modeling the multivariate relationships.

Results: Results showed that contraceptive use varied significantly by state of residence. It increased (odds $=3.6, \mathrm{p}-$ value $=0.000$ ) for respondents with higher education compared to the uneducated. Also it increased (odds $=2.84$, Pvalue $=0.000)$ for the richest sub-group compared to the poorest/poorer category. The odds of using contraceptive increased (odds $=2.20, \mathrm{P}$-value $=0.000$ ) for respondents who preferred no other child compared to their counterparts who preferred to have additional; and it decreased (odds $=0.37$, P-value $=0.000$ ) for those who had two or fewer children compared to those who had three or more.

Conclusions: Policies and programme intervention should consider education, wealth status, and preference for additional child, and number of living children as key to increasing contraceptive uptake in the region.

Keywords: Agents of modernity, Contraceptive use, Fertility preference, Number of living children, Women in marital relationship

\section{INTRODUCTION}

Nigeria's population of 187 million is among the fastest growing with a potential to increase to 398 million making it the fourth largest in the world by year $2050 .^{1}$ The fast growth inertia of Nigeria's population is mainly due to a persistently high fertility rate which was 5.7 in 2003 and slightly dropped by $0.2 \%$ in 10 years to 5.5 in $2013 .^{2,3}$ Coupled with high fertility rate is the paradox of low modern contraceptive use, along with high level of knowledge about the device. ${ }^{3-7}$ In 2003 , only $8.2 \%$ of married women used modern contraceptives whereas $78.4 \%$ reported knowledge about it, and in 2013 only $10 \%$ used while $82.8 \%$ reported knowledge. ${ }^{2,3}$ All regions and states of the country have similar statistics though at various degrees. This study examines factors influencing contraceptive use in south-west region of Nigeria which has lower total fertility rate (4.6) than the national 
average and has the highest modern contraceptive use rate $(24.9 \%)$ as well. The aim is to use the findings from this study to shed more insight on strategies to bring about decline in the region, and other regions of the country.

Evidence in the literature showed that contraceptive use is influenced by socioeconomic and demographic factors. ${ }^{4,8-11}$ In this study, socioeconomic and demographic factors (classified as background factors) include age, residence (both state, and rural-urban), education, religion, wealth status, number of siblings, and birth order. Contraceptive use has a positive relationship with age i.e. older respondents are more likely to use than their younger counterparts. ${ }^{12-15}$ Also, studies suggest that at younger ages 35 and below which is the beginning of reproductive life, age differentials in contraceptive use may not be that significant. ${ }^{6}$

Studies show that contraceptive use varies significantly by ethnicity, and by location which may be regional or rural-urban residence. . $^{12,14,16,17} \mathrm{~A}$ key consistent determinant of contraceptive use in the literature is education. 4,8,16,18,19 Evidence show that women with higher level of education use contraceptive more than those with lower or uneducated. ${ }^{12,14,17,19-25}$ The positive impact of education on contraceptive use is more when both husband and wife are educated. ${ }^{15}$

Religion significantly influences contraceptive use in diverse ways. ${ }^{4,8,9,11,12,15,26}$ Religious influence on contraceptive use are often context and location specific like in Malawi where evidence showed that Catholic were more likely than Muslims or Pentecostals to use contraceptive, and in rural western Kenya, evidence showed that religion had no effect on contraceptive use. ${ }^{19,27}$ Another socioeconomic factor with significant relationship with contraceptive use is wealth status. ${ }^{4,25,28}$ The literature suggest that women with high socioeconomic status use contraceptives more than those with low wealth status. ${ }^{11,12,17,23}$ Contraceptive use is influenced by work status that is women who worked used contraceptive more than their counterparts who did not work..$^{20,23,28}$ The effect of work on contraceptive use is more with paid employment, which empowers women to exercise their right to determine contraceptive use. ${ }^{8}$

The literature showed that key agents of modernity that may influence behaviour change include electricity television, mobile phone. ${ }^{29-32}$ These agents of modernity were included in models designed to examine factors influencing contraceptive use in the region. The literature confirms strong positive relationship between contraceptive use and number of living children. ${ }^{13,15,17,23,26}$ Women who have more living children are often more likely to have attained or close to attaining their reproductive goals, and thus use contraceptive more. Another key determinant of contraceptive use suggesting spacing or stopping fertility behavior is preference for another child. ${ }^{16,33}$
This paper examines the relationships between background factors of women and their husbands/partners, intermediate factors such as employment and fertility behaviour factors and contraceptive use with the aim of providing more insight on ways of reducing fertility levels further, and increase contraceptive use in the region, and other regions in the country.

\section{METHODS}

The paper analyzed the Nigeria Demographic and Health Survey (NDHS) nationally representative cross-sectional data, was conducted in 2013 in the entire 36 states, and the Federal Capital territory (FCT) of Nigeria. The NDHS was designed to provide population and health related information and serve as a platform for health systems development planning efforts in Nigeria. The 2013 NDHS used three-staged stratified cluster design with sampling and data collection conducted at three levels i.e. the State, Local Government Authority (LGA), and Community or Enumeration Area (EA). About 39,902 women aged 15-49 were eligible for the study and $38,945(98 \%)$ successfully completed the survey questionnaire.

The fieldwork of this study was conducted from February to July 2013 and it represents 3784 women in marital relationship aged 15-49 located in south-west region of Nigeria. The NDHS was conducted at the same period simultaneously in the six geopolitical regions of the country and the Federal Capital Territory (FCT).

The total representative sample for the NDHS was 38,945 women aged 15-19. The 3784 women on marital relationship included in this study was a sub-sample extracted from the nationally representative sample. These are women aged 15-49 who were either married or living with a man at the time that the NDHS was conducted.

The ultimate dependent variable in this study is contraceptive use (using vs. not using), and the intermediate dependent variable is fertility behavior, measured by (1) number of living children, and (2) fertility preference (want another child or not). Number of living children is defined as children of women aged 15-49 alive during the survey, and fertility reference is measured by a question that asked whether respondent preferred to have another child.

The second intermediate dependent variable is employment measured as; work status (working vs. not working), type of work (either not working/others, technical/services, agricultural, or skilled/unskilled manual labour), and earnings from work (not working vs. cash/kind, or cash only). The agents of modernity included in this study are availability of electricity, radio, television (TV), cable TV, house telephone and mobile phone. The independent variables are background 
characteristics of the women and selected background characteristics of their husband/partner. Background characteristics of the respondent include age, state of residence, urban-rural residence, education, religion, wealth index (status), number of respondents' siblings, and birth order of respondent, and husband's background factors are age, education, and type of work.

\section{Statistical analysis}

Analysis employed SPSS Version 20 and it involved univariate, and multivariate models. The Univariate analysis ran frequency distribution of all the variables used in the study thus suggesting skewness or normality. And the multivariate analysis presents two models using logistic regression techniques which provide information on direct and indirect relationships among the dependent and independent variables.

\section{RESULTS}

\section{Background factors of respondents and their spouse}

Table 1 below shows that the majority of the respondents were aged 30 and older $(68 \%)$, lived in urban areas (71\%), had secondary or higher education (64\%), were Christians (67\%), and of the richer/richest wealth category $(78 \%)$.

Also, the Table shows that respondents were fairly distributed across the six south-west states with the largest in Lagos state (24.2\%), followed by Oyo (17.8\%), Osun $(16.1 \%)$, Ondo $(13.7 \%)$, Ekiti $(13.7 \%)$, and Ogun (12.9\%). Most respondent (Table 1) were working at the time of study (90\%), with the majority in technical/services profession $(71 \%)$ and were paid cash for work $(83 \%)$.

Results in Table 2 above show that the majority of respondents $(90 \%)$ were from families of at least three siblings and were not first-born (79\%). Most husband/partners of respondents were aged 35 years or older $(75 \%)$, had at least secondary education $(70 \%)$, and were either agricultural or skilled/unskilled laborers $(57 \%)$.

\section{Descriptive statistics on agents of modernity, fertility, and contraception}

Table 2 shows that most respondents had electricity $(80.4 \%)$, radio $(79.7 \%)$, TV $(76.4 \%)$, and mobile phone (92.6\%), and smaller proportion had cable TV (14.2\%) and telephone $(1.5 \%)$. Results in Table 2 below show that most respondents $(79.4 \%)$ reported that they had three or more agents of modernity.

Table 2 shows that the majority of respondents reported listening to radio less than once a week (62\%) and watched TV at least once a week $(61 \%)$. The table also shows that less than half $(41 \%)$ of respondents had at most two living children, the majority $(62 \%)$ reported preference for another child, and about a third (36\%) used contraceptives.

Table 1: Background characteristics of women in marital union aged 15-49 and that of their husbands in South-West region of Nigeria.

\begin{tabular}{|c|c|c|c|}
\hline Variables & & Total, $(\mathrm{N})=3784$ & $\%$ \\
\hline Respondents & background & & \\
\hline & 24 or less & 434 & 11.5 \\
\hline Age group & $25-29$ & 784 & 20.7 \\
\hline & $30-34$ & 803 & 21.2 \\
\hline respondents & $35-39$ & 743 & 19.6 \\
\hline & $40+$ & 1020 & 27.0 \\
\hline & Oyo & 674 & 17.8 \\
\hline & Ogun & 490 & 12.9 \\
\hline State of & Lagos & 917 & 24.2 \\
\hline residence & Osun & 611 & 16.1 \\
\hline & Ekiti & 518 & 13.7 \\
\hline & Ondo & 574 & 15.2 \\
\hline Place of & Rural & 1082 & 28.6 \\
\hline residence & Urban & 2702 & 71.4 \\
\hline & No education & 440 & 11.6 \\
\hline Level of & Primary & 918 & 24.3 \\
\hline education & Secondary & 1751 & 46.3 \\
\hline & Higher & 675 & 17.8 \\
\hline & Islam/traditional & 1267 & 33.5 \\
\hline Religion & Christianity & 2510 & 66.5 \\
\hline & Poorest/poorer & 347 & 9.2 \\
\hline $\begin{array}{l}\text { Wealth } \\
\text { index }\end{array}$ & Middle & 480 & 12.7 \\
\hline $\begin{array}{l}\text { index } \\
\text { (status) }\end{array}$ & Richer & 1145 & 30.3 \\
\hline & Richest & 1812 & 47.9 \\
\hline No. of & 2 or less & 395 & 10.4 \\
\hline respondent's & $3-5$ & 1873 & 49.5 \\
\hline siblings & 6 or more & 1513 & 40.0 \\
\hline Birth order & First child & 778 & 21.0 \\
\hline & Second or third child & 1434 & 38.7 \\
\hline respondent & Forth child or higher & 1490 & 40.2 \\
\hline & Not working & 377 & 10.0 \\
\hline Work status & Working & 3398 & 90.0 \\
\hline & Not working/others & 363 & 9.6 \\
\hline & Technical/services & 2687 & 71.1 \\
\hline $\begin{array}{l}\text { 1 ype of } \\
\text { work }\end{array}$ & Agricultural & 335 & 8.9 \\
\hline & $\begin{array}{l}\text { Skilled/unskilled } \\
\text { manual }\end{array}$ & 394 & 10.4 \\
\hline & Not working & 364 & 9.6 \\
\hline $\begin{array}{l}\text { Earnings } \\
\text { from work }\end{array}$ & Cash or kind & 285 & 7.5 \\
\hline & Cash only & 3135 & 82.8 \\
\hline Husband's & 34 or younger & 959 & 25.3 \\
\hline background & $35-49$ & 1966 & 52.0 \\
\hline $\begin{array}{l}\text { Husband's } \\
\text { age in group }\end{array}$ & 50 or older & 859 & 22.7 \\
\hline & No education & 386 & 10.2 \\
\hline Husband's & Primary & 765 & 20.2 \\
\hline education & Secondary & 1729 & 45.8 \\
\hline & Higher & 899 & 23.8 \\
\hline & Not working/others & 62 & 0.6 \\
\hline Husband's & Technical/services & 1570 & 41.6 \\
\hline type of work & Agricultural & 806 & 21.4 \\
\hline & Skilled/unskilled mar & 1333 & 35.3 \\
\hline
\end{tabular}


Table 2: Frequency distribution of agents of modernity, frequency of exposure, fertility behavior and contraceptive use in South-West region of Nigeria.

\begin{tabular}{|c|c|c|}
\hline Variables & Total $(\mathbf{N})=3784$ & (in \%) \\
\hline \multicolumn{3}{|l|}{ Agents of modernity } \\
\hline \multicolumn{3}{|l|}{ Household has electricity } \\
\hline No & 742 & 19.6 \\
\hline Yes & 3038 & 80.4 \\
\hline \multicolumn{3}{|l|}{ Household has Radio } \\
\hline No & 768 & 20.3 \\
\hline Yes & 3015 & 79.7 \\
\hline \multicolumn{3}{|l|}{ Household has TV } \\
\hline No & 894 & 23.6 \\
\hline Yes & 2888 & 76.4 \\
\hline \multicolumn{3}{|l|}{ Household has cable TV } \\
\hline No & 3238 & 85.8 \\
\hline Yes & 538 & 14.2 \\
\hline \multicolumn{3}{|l|}{ Household has telephone } \\
\hline No & 3711 & 98.5 \\
\hline Yes & 57 & 1.5 \\
\hline \multicolumn{3}{|l|}{ Has mobile phone } \\
\hline No & 279 & 7.4 \\
\hline Yes & 3466 & 92.6 \\
\hline \multicolumn{3}{|l|}{ Cumulative index of modernity } \\
\hline None & 138 & 3.6 \\
\hline One item & 226 & 6.0 \\
\hline Two items & 417 & 11.0 \\
\hline Three or more items & 3003 & 79.4 \\
\hline \multicolumn{3}{|c|}{$\begin{array}{l}\text { Frequency of exposure to agents of modernity } \\
\text { Frequency listened to radio }\end{array}$} \\
\hline Not at all & 522 & 13.8 \\
\hline Less than once a week & 918 & 24.3 \\
\hline At least once a week & 2341 & 61.9 \\
\hline \multicolumn{3}{|l|}{ Frequency watched TV } \\
\hline Not at all & 604 & 16.0 \\
\hline Less than once a week & 869 & 23.0 \\
\hline At least once a week & 2309 & 61.1 \\
\hline \multicolumn{3}{|l|}{ Fertility behaviour } \\
\hline \multicolumn{3}{|l|}{ No of living children } \\
\hline Three or more & 2253 & 59.5 \\
\hline Two or less & 1531 & 40.5 \\
\hline \multicolumn{3}{|l|}{ Preference for another child } \\
\hline Favorable to another child & 2345 & 62.1 \\
\hline Not favorable to another child & 1429 & 37.9 \\
\hline \multicolumn{3}{|l|}{ Contraceptive use } \\
\hline Not using & 2417 & 63.9 \\
\hline Using & 1367 & 36.1 \\
\hline
\end{tabular}

\section{Multivariate results}

\section{Reduced model I and full II}

The benchmark for interpreting logistic regression results is 1 , and values more than 1 are interpreted as increased odds while values less than 1 are interpreted as decreased odds. In Table 2, Model I examined the medicating effects of fertility behaviour factors, and Model II is the full model including all predictors in the equation. Clearly the best fitted of the two models is Model II with the lowest -2 log likelihood of 4122.27 and explained 
variance (Nagelkerke R2) of $20 \%$ compared to Model I with $-2 \log$ likelihoods of 4137.36 and explained variance of $19 \%$. The strong mediating effects of fertility behavior were evident in both models which produced similar results in terms of significant predictors and direction of effects, thus, this paper explains only Model II results.

Table 3: The odds that women in marital relationship in south-west region of Nigeria used contraceptives according to respondents' background factors, agents of modernity, employment, and fertility behaviour factors.

\begin{tabular}{|c|c|c|}
\hline Variables & Reduced Model I & Full Model II \\
\hline $\begin{array}{l}\text { Respondents' background } \\
\text { Age (in single years) } \\
\text { State of Residence } \\
\text { Oyo (ref.) }\end{array}$ & 0.93 & 0.93 \\
\hline Ogun & $0.49 * * *$ & $0.48 * * *$ \\
\hline Lagos & 1.12 & 1.12 \\
\hline Osun & $0.69 * *$ & $0.69 * *$ \\
\hline Ekiti & $0.61 * * *$ & $0.61 * * *$ \\
\hline Ondo & $0.70^{*}$ & $0.69 *$ \\
\hline \multicolumn{3}{|l|}{ Residence } \\
\hline \multicolumn{3}{|l|}{ Rural (ref.) } \\
\hline Urban & 1.13 & 1.13 \\
\hline \multicolumn{3}{|l|}{ Education } \\
\hline \multicolumn{3}{|l|}{ No education (ref.) } \\
\hline Primary & $2.55 * * *$ & $2.60 * * *$ \\
\hline Secondary & & $2.66 * * *$ \\
\hline Higher & $2.59 * * *$ & $3.63 * * *$ \\
\hline \multicolumn{3}{|l|}{ Religion } \\
\hline Islam/traditional (ref.) & $3.53 * * *$ & 1.01 \\
\hline \multicolumn{3}{|l|}{ Christianity wealth index } \\
\hline \multicolumn{3}{|l|}{ Poorest/poorer (ref.) } \\
\hline Middle & 1.02 & $2.00 * *$ \\
\hline Richer & $2.02 * *$ & $2.09 *$ \\
\hline Richest & $2.10^{*}$ & $2.84 * * *$ \\
\hline \multicolumn{3}{|l|}{ No of siblings of respondent } \\
\hline 2 or less (ref.) & $2.86^{* * *}$ & \\
\hline $3-5$ & 1.10 & 1.11 \\
\hline 6 or more & 1.11 & 1.12 \\
\hline \multicolumn{3}{|l|}{ Birth order of respondent } \\
\hline \multicolumn{3}{|l|}{$1^{\text {st }}$ child (ref.) } \\
\hline $2^{\text {nd }}$ or $3^{\text {rd }}$ child & 1.15 & 1.14 \\
\hline $4^{\text {th }}$ child or higher & 1.06 & 1.05 \\
\hline Variables & Model I & Model II \\
\hline \multicolumn{3}{|l|}{ Husband's background } \\
\hline $\begin{array}{l}\text { Husband's Age (in single years) Husband's Education } \\
\text { No education (ref.) }\end{array}$ & $0.98 * * *$ & $0.98 * * *$ \\
\hline Primary & 0.79 & 0.79 \\
\hline Secondary & 0.74 & 0.74 \\
\hline Higher & 0.81 & 0.81 \\
\hline \multicolumn{3}{|l|}{ Husband's type of work not working/others (ref.) } \\
\hline Technical/services & 1.64 & 1.67 \\
\hline Agricultural & 1.66 & 1.68 \\
\hline Skilled/unskilled manual & 1.78 & 1.84 \\
\hline \multicolumn{3}{|l|}{$\begin{array}{l}\text { Agents of modernity household has electricity } \\
\text { No (ref.) }\end{array}$} \\
\hline Yes & 1.16 & 1.16 \\
\hline
\end{tabular}




\begin{tabular}{|c|c|c|}
\hline Variables & Reduced Model I & Full Model II \\
\hline Yes & 0.99 & 0.99 \\
\hline \multicolumn{3}{|l|}{ Household has TV No (ref.) } \\
\hline Yes & 1.24 & 1.24 \\
\hline \multicolumn{3}{|l|}{ Household has cable TV } \\
\hline $\begin{array}{l}\text { No (ref.) } \\
\text { Yes }\end{array}$ & 1.09 & 1.10 \\
\hline \multicolumn{3}{|l|}{ Has telephone phone No (ref) } \\
\hline Yes & 1.40 & 1.43 \\
\hline \multicolumn{3}{|l|}{ Has mobile phone No (ref) } \\
\hline Yes & 0.95 & 0.94 \\
\hline \multicolumn{3}{|c|}{ Cumulative index of modernity none (ref.) } \\
\hline One item & 1.86 & 1.87 \\
\hline Two item & 1.92 & 1.93 \\
\hline Three or more & 1.27 & 1.29 \\
\hline \multicolumn{3}{|c|}{$\begin{array}{l}\text { Frequency of exposure to agents of modernity } \\
\text { Frequency listened to radio not at all (ref.) }\end{array}$} \\
\hline Less than once a week & 1.13 & 1.11 \\
\hline At least once a week & 1.24 & 1.23 \\
\hline \multicolumn{3}{|c|}{ Employment factors work status not working (ref.) } \\
\hline Working & - & 1.15 \\
\hline Technical/services & - & 2.09 \\
\hline Agricultural & - & 2.05 \\
\hline Skilled/unskilled manual & - & 1.87 \\
\hline \multicolumn{3}{|c|}{ Earnings from work not working (ref.) } \\
\hline Cash or kind & - & 0.51 \\
\hline Cash only & - & 0.42 \\
\hline \multicolumn{3}{|c|}{ Number of living children three or more (ref.) } \\
\hline Not favorable to another child & $2.19 * * *$ & $2.20 * * *$ \\
\hline At most two & $0.36 * * *$ & $0.37 * * *$ \\
\hline
\end{tabular}

Ref. $=$ reference category, Significance level: $*=0.05, * *=0.01$, and $* * *=0.001$ levels of significance. Model I: Contraceptive status by background factors, agents of modernity, fertility behavior factors: Total $\mathrm{N}=3784,-2$ Log Likelihood $=4137.36$, Nagelkerke $\mathrm{R}^{2}=$ 0.19, (explained variance $=19 \%$ ). Model II: Contraceptive status by background factors, agents of modernity, employment, and fertility behavior factors: Total $\mathrm{N}=3784,-2 \log$ likelihood $=4122.27$, Nagelkerke $\mathrm{R}^{2}=.20$ (explained variance $\left.=20 \%\right)$.

\section{Factors influencing contraceptive use among women in marital relationship}

Table 3 shows the relationships between contraceptive use and background factors of women in marital relationships and that of their husbands, agents of modernity, employment, and fertility behaviour factors.

Findings in Table 3, Model II show that respondent's state of residence, education, wealth status, husband/partner's age, fertility preference and number of living children had consistent significant effects on contraceptive use. The odds of contraceptive use decreased to 0.48 times $(\mathrm{P}$-value $=.000)$ for respondents in Ogun state compared to their counterparts in Oyo state, and for respondents in Osun, Ekiti, and Ondo states, the odds decreased to $0.69(\mathrm{P}$-value $=0.008), 0.61(\mathrm{P}$-value $=$ $0.001)$, and 0.69 (p-value $=0.014)$ times respectively compared to the reference category. As presented in Table 3, the odds of contraceptive use increased by 2.60 times $(\mathrm{P}$-value $=.000)$ for primary level educated respondents compared to their uneducated counterparts, and for those with secondary, and higher levels, the odds increased to $2.66(\mathrm{P}$-value $=0.000)$, and $3.63(\mathrm{P}$-value $=$ $0.000)$ times respectively compared to their uneducated counterparts. Likewise, the odds of contraceptive use increased significantly by wealth status from 2.00 times (P-value $=0.006)$ for those in the middle level wealth status, to 2.09 times $(\mathrm{P}$-value $=0.014)$ for those in the richer, and 2.84 times $(\mathrm{P}$-value $=0.001)$ for those in the richest category compared to their counterparts in the poorest/poorer referenced category. The results show that the odds of contraceptive use for respondents decreased to 0.98 times $(\mathrm{P}$-value $=0.000)$ with additional unit increase in husband's age.

Results in Table 3 shows that the effects of fertility behaviour factors on contraceptive use were strong and consistent in both Models I and II (Table 2). In Model II, the odds of contraceptive use increased significantly by 2.20 times $(\mathrm{P}$-value $=0.000)$ for respondents who had no preference for another child compared to those who had 
preference. As expected in a high fertility regime, the odds of contraceptive use decreased significantly to 0.37 times ( $\mathrm{p}$-value $=0.000$ ) for respondents who had at most two children compared to those who had three or more (Table 2).

\section{DISCUSSION}

In a region that is currently experiencing signs of fertility decline partly due to increased contraceptive use (NDHS, 2013), it is important to examine enabling factors that will ensure sustained continuous increase in the future. This may serve as a reference point for neighboring regions in the country. The study included 3784 women in marital relationship in the south-west region of Nigeria extracted from the NDHS of 2013.

Findings of this study showed specific significant variations in contraceptive use in the region. The odds of contraceptive use were higher among Oyo state respondents compared to their counterparts in Ogun, Osun, Ekiti, and Ondo states. Factors influencing state specific variations in contraceptive use need to be teased out and tackled to increase use in all the states of the region. Similar to results of other studies in the region, religion has no significant effects on contraceptive use. ${ }^{22}$ Likewise; employment factors do not have significant effects on contraceptive use. Reasons may be partly due to weak instruments used to capture employment in the NDHS. Questions on employment status i.e. working or not working, or on type of work i.e. professional/service, skilled/unskilled manual work do not have opportunity cost imbued in them to reflect decisions or actions in favor of contraceptive use. In order for employment variables to significantly impact fertility behaviors and contraceptive use, monetary value and/or status symbol such as cadre or position e.g. managerial, middle level, or years of work experience etc., must be implicit in any effective measure of the employment variable. ${ }^{34}$

This study corroborates evidence in the literature on the positive effects of mother's education on contraceptive use. ${ }^{12,14,16,17,20-25}$ Results of this study showed that the odds of contraceptive use almost tripled for respondents with primary and secondary level education, and were about four times for those with higher education compared to the uneducated. Policies that strengthens girls' education will eventually yield the desired results of replacement level fertility in the region in the long-run. Over 10 years evidence from the NDHS suggest that women with the highest level of education used contraceptive more than those with lower or no education. ${ }^{2,3}$ In addition, the odds of contraceptive use favor those in the middle and high socioeconomic status. ${ }^{11,12,17,23}$ It looks like the wealthy class contrary to pro-natalist behavior of the past have over the years, become more embracing of family planning programs.

Interestingly, while the effects of respondents' age on contraceptive use were not significant, that of husband/partners' age was negatively significant. The result is not unexpected in a society underpinned by male hegemony and the influence of husband/partners in decision-making on crucial household issues like contraceptive use. ${ }^{6,10}$ As the study results suggest, male influence is probably more among the older generation of husband/partners than the younger generation and thus, age differentials in policies and programs geared towards increase contraceptive use should be pursued vigorously in the region.

Findings of this study established the positive relationships between contraceptive use and fertility behavior. Respondents who reported non-preference for another child used contraceptives more, perhaps for spacing of births rather than for limiting since the odds for using were far reduced for respondents who had two or fewer children. ${ }^{6,16,35}$ These results of fertility behavior may suggest potential or latent unmet need for spacing of births that could transition to increased contraceptive use, and perhaps liming behavior in the future especially with concerted program effort in the region.

The only possible effects of agents of modernity observed in the analysis reflected in the best-fitted models with more explained variance. Since electricity, radio, TV and telephones among others are agents of massive transformation they might hold the key to ideational change in thinking and behavior towards massive increase in contraceptive use if well appropriated as vehicle of change by family planning policies stakeholders and program implementers. ${ }^{29-32}$

\section{CONCLUSION}

This study was conducted to shed more light on the key predictors of contraceptive use in the south-west region of Nigeria with a view to increasing use among women in marital relationships and thus, reduce high fertility in the region. Evidence of this study showed that effective and successful policies and programming strategies on family planning would need to take into consideration differences among states, level of education, wealth status, husband's age, number of living children, and women's fertility preference, and number of living children for it to have positive impact on contraceptive use and reduce fertility in the region. The study suggests possible increase contraceptive use in the region if these factors are applied in designing family planning programs taking into consideration agents of change that may be instrumental in driving contraceptive uptake to a conclusive end.

\section{ACKNOWLEDGMENTS}

Authors would like to appreciate Demographic and Health Survey (DHS) Program, USA for proving access to the data used for this study. And also thank Covenant University, Ota, Nigeria for providing support and assistance needed. 
Funding: No funding sources

Conflict of interest: None declared

Ethical approval: None required

\section{REFERENCES}

1. Population Reference Bureau (PRB). World Population Data Sheet; 2016. Available at: www.prb.org/pdf16/prb-wpds2016-web-2016.pdf.

2. National Population Commission (NPC) (Nigeria) and ICF International. Nigeria Demographic and Health Survey 2003, 2004. Abuja, Nigeria, and Rockville, Maryland, USA: NPC and ICF International. Available at: https://dhsprogram.com/publications/publicationsby-country.cfm.

3. National Population Commission (NPC) [Nigeria] and ICF International. Nigeria Demographic and Health Survey 2013, 2014. Abuja, Nigeria, and Rockville, Maryland, USA: NPC and ICF International. Available at: https://dhsprogram.com/publications/publicationsby-country.cfm.

4. Odewale JB, Oladosun M, Amoo EO. Fertility Desire and Contraceptive Use among Women in Nigeria, 2016. 3rd International Conference on African Development Issues. ISSN: 2449-075X.

5. Avidime S, Aku-Akai L, Mohammed AZ, Adaji S, Shittu O, Ejembi C. Fertility Intentions, Contraceptive Awareness and Contraceptive Use among Women in Three Communities in Northern Nigeria, 2010. African J Reproduct Health. 2010.

6. Sedgh G, Bankole A, Oye-Adeniran B, Adewole IF, Singh S, Hussain R. Int Family Planning Perspect. 2006;32(4):175-84.

7. Oyedokun AO. Determinants of Contraceptive Usage: Lessons from Women in Osun State, Nigeria. J Humanities Social Sci. 2007;1(2):ISSN 1934-7227.

8. Unumeri GS, Babatunde I, Oginni AA. Contraceptive Use and Its Socio-economic Determinants among Women in North-East and North-West Regions of Nigeria: A Comparative Analysis. African Population Studies. 2015;29(2).

9. Igbodekwe CF, Oladimeji O, Oladimeji KE, Adeoye IA, Akpa OM, Lawson L. Utilisation of Modern Contraceptive among Women Of Childbearing Age in Resource Constraint Setting: Evidence from 2008 National Demographic and Health Survey in Nigeria. J Health Sci. 2014;4(3): 72-78.

10. Olugbenga-Bello AI, Abodunrin OL, Adeomi AA. Contraceptive practices Among Women in Rural Communities in South- Western Nigeria. Global J Med Res. 2011;11:ISSN: 0975-5888.

11. Okech CT, Wawire NW, Mburu TK. Contraceptive Use among Women of Reproductive Age in Kenya City Slums. Int J Business Social Sci. 2011;2(1).

12. Thomas EM, Harutyunyan TL. Contraceptive Practices in Armenia. Panel Evaluation of an Information -Education-Communication Campaign. J Social Sci Med. 2006;63:2770-2783.
13. Frini, $\mathrm{OH}$, Omer W, Nabag M. The Knowledge and determinant factors of contraceptive use among married Sudanese Women. Applied Science Reports. 2013:E-ISSN:2310-9440.

14. Odimegwu OC. Family Planning Attitudes and Use in Nigeria: A Factor Analysis. International family planning perspectives. 1999;25(2).

15. Islam AM, Padmadas SS, Smith PWF. Understanding family planning communication between husbands and wives: multilevel analysis of wives responses from Bangladesh. DHS Genus. 2010;66(1):1-15.

16. Asiimwe BJ, Ndugga P, Mushomi J, Patrick J, Ntozi M. Factors associated with modern contraceptive use among young and older women in Uganda comparative analysis. BMC Public Health. 2014;14:926.

17. Fikree, FF, Khan A, Kadir MM, Sajan F, Rahbar MH. What Influences Contraceptive Use among Young Women in Urban Squatter Settlements of Karachi, Pakistan. International Family Planning Perspectives. 2001;27(3):130-6.

18. Feyisetan BJ, Bankole A. Martha Ainsworth. Contraceptive Use and the Quality, Price and Availability of Family Planning in Nigeria. Oxford Journals. The World Bank Economic Review. 2016;10(1):159-87.

19. Bakibinga $P$, Mutobo N, Mukiira C, Kamande C, Ezeh A, Muga R. The Influence of Religion and Ethnicity on Family Planning Approval: A Case for Women in Rural Western Kenya. Journal of Religion Health 2015.

20. Lakew Y, Reda AA, Tamene H, Benedict S, Deribe K. Geographical variation and factors influencing modern contraceptive use among married women in Ethiopia: Evidence from a national population based survey. J Reproductive Health. 2013.

21. Osakinle EO, Babatunde JO, Alade FA. Youths and their choice of contraceptives towards an effective reproductive health: the case of Ekiti state, Nigeria. European Scientific Journal. 2013;9(9):ISSN: 1857 7881(Print); - ISSN 1857-7431.

22. Olaitan OL. Factors influencing the choice of family planning among couples in Southwest Nigeria. Int J Med Sci. 2011;3(7):227-32.

23. Kamal SMM. Contraceptive Use and Method Choice in Urban Slum of Bangladesh 2009. International Conference on Family Planning: Research and Best Practices 2009. Available at: fpconference.org/2009/media/DIR_169701/15f1ae85 7ca97193ffff83a4ffffd524.pdf.

24. Sahoo H. Determinants of Contraceptive Use in Orissa: An Analysis from National Family Health Survey III. Health and Population Perspectives and Issues. 2007;30(3):208-21.

25. Valente WT, Saba WP. Campaign Exposure and Interpersonal Communication as Factors in Contraceptive Use in Bolivia. J Health Communicat. 2001;6:303-22. 
26. Parr N. Mass Media Promotion of Family Planning and the Use of Modern Contraception in Ghana. 24th IUSSP General Conference; 2001. Available at: http:/www.iussp.org/Brazil2001/index.php.

27. Yeatman ES, Trinitapoli J. Beyond Denomination: The relationship between religion and family planning in rural Malawi. Demographic Research. 2008;19(55):1851-82.

28. Aragaw AK. Application of Logistic Regression in determining the Factors Influencing the Use of Modern Contraceptive among married women in Ethiopia 2015. Am J Theoretical Applied Stat. 2015;4(3):156-62.

29. Silvast A, Virtanen MJ. Keeping systems at work: electricity infrastructure from control rooms to household practices. Science Technology Studies. 2014;27(2):93-114

30. Zhuk S. Hollywood's insidious charms: the impact of american cinema and television on the soviet union during the cold war. Cold War History. 2014;14(4):593-617.

31. Kyem PAK, LeMaire PK. Transforming recent gains in the digital divide into digital opportunities: Africa and the boom in mobile phone subscription. Electronic Journal of Information Systems in Developing Countries. 2006;289. Available at: http://www.ejisdc.org/ojs2/index.php/ejisdc/article/vi ew/343.
32. Kyem PAK. Is ICT the panacea to sub-Saharan Africa's development problems? Rethinking Africa's contentious engagement with the global information society. Progress in Development Studies. 2012;12(2-3):231-44.

33. Oyediran AK, Isiugo-Abanihe UC. Husband-wife communication and couple's fertility desires among yoruba of Nigeria. J African Populat Studies. 2002;17(2):61-80.

34. Oladosun, M, George, T, Abioye T, Olawole-Isaac A, Adekoya DO. Socio-demographic factors, employment status, and fertility behavior of women in marital union in South-West Region of Nigeria; 2017. Available at: https://www.researchgate.net/ publication/332531326_SES_Emp_Fert_Bev_in_SW _Nig_FINAL_101017.

35. Fayehun OA, Omololu OO, Isiugo-Abanihe UC. Sex of preceding child and birth spacing among Nigerian ethnic groups. African J Reproduct Health. 2011;15(2):79.

Cite this article as: Oladosun M, Akanbi M, Fasina F, Samuel O. Key predictors of modern contraceptive use among women in marital relationship in SouthWest region of Nigeria. Int J Reprod Contracept Obstet Gynecol 2019;8:2638-46. 